\title{
Instagram Picture Series to Improve Students' Procedure Text
}

\author{
Vebryary Eka Rahmawati, ${ }^{1, *}$, Lailatul Musyarofah ${ }^{2}$ \\ ${ }^{1,2}$ STKIP PGRI Sidoarjo, Indonesia \\ *Corresponding author. E-mail address: vebriaryeka@gmail.com
}

\begin{abstract}
The research is aimed to know whether the students' ability in writing procedure text be improved through the use of Instagram picture series as teaching media. This is a classroom action research (CAR) on the eleventh grade of Madrasah Aliyah NU Sidoarjo in 2018/2019 academic year. The researchers used the CAR model developed by Kemmis and Mc Taggart (1990) which includes four steps. They are planning, acting, observing and reflecting. This research used quasi-experimental design. Participants were equally assigned to experiment group and control group. The population is 126 students. The samples are ten students of XI MIPA 1 as the experimental group and ten students of XI MIPA 1 XI MIPA 2 as the control group. The researcher applied two kinds of instrument: writing pre-test and writing post-test. The data was analyzed statistically using T-test. As the result, the percentage growth's margin between experimental group and control group is $4.52 \%$. The use of Instagram picture series as teaching media was an appropriate strategy for eleventh grade students of Madrasah Aliyah NU Sidoarjo to improve their ability in writing procedure text. It means that, the use of Instagram picture series as teaching media had the significant positive impact to the improvement of the students' ability in writing procedure text.
\end{abstract}

Keywords: Instagram picture series, procedure text, improvement, CAR.

\section{INTRODUCTION}

Writing skill has the lowest percentage of achievement of all the communicative skills based on the average score observation toward the eleventh grade students of Madrasah Aliyah NU Sidoarjo during 2018-2019 academic year. Moreover, the result of questionnaire shows that most of the students $(76.5 \%)$ found difficulty in writing. Some of them found difficulties in developing paragraph and finding proper vocabulary. Some ofthem did not recognize the correct spelling of some certain words. According to Hadfield and Hadfield (2004, p. v), there are some difficulties linked to the writing. Firstly, there is psychological difficulty in which the writer has to choose what the information the reader needs and how best to state this. Secondly, there is linguistic difficulty in that the language used in written language is diverse from that used in speech. Thirdly, there is cognitive difficulty in which that the students have to arrange their thought on paper. That is why writing is identified as the most difficult language skill to learn for a language learner.

Specifically, it was found that the students' ability in writing procedure text was still far from what was estimated. From the result of the students' writing, the average score was 54.25. It was distressing because the material about procedure text is commonly found in students' daily life. There are many examples of procedure text. Those are directions which are used for giving instructions about where to go, recipes which are the set of instructions for preparing a food dish, and many appliance manuals. Based on the depth interview, most 
of students said that the way of teaching is dominant factor of their failure in writing. The teacher seldom taught writing to the students through writing process which only gave the students to write in a certain topic without any supervision and interesting teaching media.

\section{PROCEDURE TEXT}

Tim Fasilitator Bahasa Inggris (2006, p. 79) says "Teks prosedur adalah teks yang memberi instruksi atau informasi kepada pembaca" (Procedure text is a text which gives instructions or information to readers). It is the set of steps which should be completed in the right sequence to get the goal.

The purpose of procedure text is to explain how something can be done. It means that in writing procedure text, the writer writes the actions which should have to do in chronological order. Gerot and Wignel (1994, p. 86) states that the social function of procedure text is to describe how something is accomplished through a sequence of action or steps. There are many examples of procedure text. Those are directions which are used for giving instructions about where to go, recipes which are the set of instructions for preparing a food dish, and appliance manuals which are used for planning for camping.

In mastering procedure text, the students have to know the generic structure of procedure text. They are: Goal. The goal can be the title of the text. It also can be an introductory paragraph. Materials. In this part, the writer has to indicate what they will need to make something. The materials can be a list or paragraph. Steps. In this part the writer has to indicate how something is accomplished through a sequence of actions or steps.

The procedure text also has some grammatical features, as Gerot and Wignel (1994, p. 55) states that the language features of procedure text are: Focus on specific and usually individualized participants or focus on generalized human agents (often implicit). Use of material processes (and in this text, behavioral and verbal processes). Sequences of events marked either explicitly by temporal connectives, or numbering of points, or implicitly by the ordering of steps on the page. Use of relational processes and temporal circumstances; Use of simple present tense or use of the imperatives and verbs of action, and use of conditional "if" to indicate alternative path of actions.

The procedure text also uses of simple present tense. It is often imperative verbs. The instructions in a procedure usually begin with a command such as mix, lift or add. The sentences are mostly short and sometimes include information on how the action is to be done, such as: gently mix, carefully lift, and slowly add. In the study of language, the command in procedure text are verbs and the how words are adverbs. In writing procedure text, use transition signals that are words such as first, second, next, finally, etc. Using transition words as a guide makes it easier for the reader to follow the ideas.

\section{TEHCNOLOGY-BASED TEACHING}

Nowadays students are well-engaged with technology especially social media. Teacher should come to the students' world to see like what they live like. Then teachers can use this phenomenon to innovatively shape their strategies and approaches in language teaching as the new form of teaching media. One of the popular photos sharing apps, serves as a great platform to share life moments with friends through a series of pictures is Instagram. Teachers can utilize Instagram by asking them to post pictures related to objects and processes of procedure text. Instagram, a popular photo sharing apps, serves as a great platform to share life moments with friends through a series of pictures. As $21^{\text {st }}$ century education system is smart enough to utilize any technology tool in a useful manner, it finds

Instagram. Teachers can utilize Instagram to engage students with science lessons by asking them to post pictures related to different science objects, processes, ecosystems, etc. Lunden 
(2014) has used the Instagram for studies and concluded that the use of media technology has helped in the process of learning.

Based on the conditions above, the writer conducted a classroom action research in order to improve the students' writing ability. The classroom action research focused on the improving students' writing ability especially in the form of procedure text by using Instagram picture series as teaching media. There are some purposes of writing. Coffin, Curry, Goodman, Hewings, Lilis, and Swann (2003, p. 20) describe writing is as an evaluation process, helping to promote critical thinking, and developing the students' communication and professionalism. Those purposes can be used based on the need of the students in the classroom in related to the different types of the writing, different audiences, and different kind of languages used in the writing. Harmer (2004) writes that teaching writing skill is different from teaching other skills. In addition, he argues that it is because "the nature of the writing process", "the need for accuracy in writing", and "the mental process that a student goes through when writing" (ibid, p. 31).

Therefore, students who are writing are significantly different from the students who are speaking. Writing needs more time and accuracy. This is further supported by Raimes who states that "learning to write is not just a "natural" extension of learning to speak" (1983, p. 3). Writing has more complexities than speaking. Students learn to speak in natural way, whereas students have to be taught at school to learn writing.

The problems arose were dealing with the competence of writing procedure text because of teaching factor, it is discussed in the review of the literature and it led in to the conclusion of adopting and implementing picture series technique to support the processes of teaching procedure text writing. Thus, the researcher expected the students improve their writing skill and develop a higher degree of participation in their learning process. At the end, there will be a significance improvement of their writing score. Research reports that many students are more visual and tactile/kinesthetic or mixed than auditory (Barbe \& Milone, 1981; Dunn, Dunn, \& Price, 1992).This evidence states that we live in a world that is visually oriented. Most of the information that our brains process comes from non-verbal stimuli (images) and even verbal information is better processed when is accompanied with visual stimuli.

Teaching procedure text can be done by some media, Instagram for example. As children of technology, students are familiar with social media which are available in their smart phone. Instagram is one of the application students can use to practice writing hence it provides picture series feature they can explore. As procedure text is explaining some procedural steps, Instagram is assumed as an appropriate medium for students practicing writing procedure text. Thus, this paper aimed at finding the effectiveness of technology, in this case Instagram, in improving students' competence in writing procedure text.

\section{METHOD}

The researcher used the Classroom Action Research model developed by Kemmis and Mc Taggart (1990, p. 14) in Penelitian Tindakan (Action Research) written by Tim PelatihPenelitian Tindakan (Action Research) Universitas Negeri Yogyakarta (2000). According to the model, the implementation of the action research includes four steps. They are planning, acting, observing and reflecting. This research used quasi-experimental design which has these criteria based on Mueller (1992, p. 38), namely 1). No random selection of subjects; 2). Pre-test both groups; 3). Experimental group receives new treatment; 4). Control group receive no treatment or the normal treatment; 4). Post-test both groups; Participants were equally assigned to experiment group and control group. The following procedures showed the research steps. Planning: the researcher was interviewing the teachers and 
students, giving questionnaire about writing, and giving pre-test on writing procedure text about making fried rice to both groups. Acting: the researcher applied the use of Instagram picture series as media on teaching writing procedure text to the experimental group. Teacher gave the example of writing procedure text by making caption and posting a picture series of making food or beverage. Then, asked the students to post their own picture and caption as the exercises. In other hand, the control group was taught without that media. Observing: the researcher gave the post-test writing procedure text about making their own favorite food or beverage to both groups. Reflecting: the researcher analyzed to what extend the use of Instagram picture series as teaching media was successful based on the criteria designed.

\section{POPULATION}

The population of the research is the eleventh grade students of Madrasah Aliyah NU Sidoarjo in academic year 2018-2019. The number of the students is 126 students which are divided into 4 classes.

\section{SAMPLE}

The technique to take the sample used by the writer was cluster sampling. This technique requires groups or clusters in taking the sample based on the group that have already existed in the population. To make it easier, the researcher took two groups as the sample. They are ten students of XI MIPA 1 as the experimental group and ten students of XI MIPA 1 XI MIPA 2 as the control group.

\section{VARIABLES}

The independent or predictor variable is Instagram picture series as media of teaching. The dependent or criterion variable is the students' ability in writing procedure text.

\section{DATA COLLECTION}

In collecting the data, the researchers applied two kinds of instrument: writing pre-test and writing post-test. Data extracted with these two instruments was assessed using a scoring rubric. The classification of the system score that the researcher used in the rubric went from 0 to 100 as follows: Poor: 0-25; Low: 30-50; Average: 55-65; Good: 70-85; Very good: 90100 .

\section{DATA ANALYSIS}

The data were analyzed statistically using T-test. The intention is to know whether there is any significant improvement of students' writing ability. After that, the researcher examine the difference between the post-test and pre-test mean of the experimental group compared with the difference between the pre-test and post-test mean of the control group. If the experimental group score is higher than the control group, it means that the independent variable is effective to improve the dependent variable.

\section{RESULTS AND DISCUSSION}

The pre-test was proposed to discover the basic writing skill of the students and it was given at the beginning of the intervention phase. It focused on the five components of narrative 
writing namely; transition or logical sequence (use of connectors), ideas (exposure), grammar and syntax (structure), vocabulary (use of parts of the speech), and word spelling contained in the scoring rubric. Both the experimental group and the control group were asked to write a procedure text about making food or beverage. Table 1 shows the pre-test scores for both groups as follows:

\section{PRE-TEST FINDING}

Table 1. Pre-test of experimental and control groups

\begin{tabular}{cccc}
\hline $\begin{array}{c}\text { Experimental } \\
\text { Group }\end{array}$ & Pre-Test Score & Control Group & Pre-Test Score \\
\hline SE1 & 45 & SC1 & 35 \\
SE2 & 30 & SC2 & 45 \\
SE3 & 50 & SC3 & 30 \\
SE4 & 65 & SC4 & 55 \\
SE5 & 45 & SC5 & 45 \\
SE6 & 50 & SC6 & 50 \\
SE7 & 35 & SC7 & 50 \\
SE8 & 40 & SC8 & 25 \\
SE9 & 50 & SC9 & 30 \\
SE10 & 45 & SC10 & 75 \\
\hline
\end{tabular}

As can be seen, the scores of the experimental group showed one (1) student with average performance, and eight (9) with low performance. On the other hand, the results from the control group showed one (1) student with good performance, one (1) student with average performance, one student with poor performance and seven (7) students with low performance.

To calculate the pre-test Mean (X) or average score (the resulting figure from the sum of individual scores (x) divided by the number of students) the researcher used the following statistical formula $X=\sum x / n$, which symbols stand for: $(X)$ the mean or average, $\left(\sum\right)$ the sum that follows (x) individual scores, and (n) stands for the number of students.

Table 2. The mean of the pre-test

\begin{tabular}{ccc}
\hline Group/ Mean & $\begin{array}{c}\text { Experimental } \\
\text { group pre-test }\end{array}$ & $\begin{array}{c}\text { Control group pre- } \\
\text { test }\end{array}$ \\
\hline Mean $\mathrm{X}$ & $\sum \mathrm{x} / \mathrm{n}$ & $\sum_{\mathrm{X}} / \mathrm{n}$ \\
$\mathrm{X}=440 / 10$ & $\mathrm{X}=\mathbf{4 5 . 5}$ & $\mathrm{X}=\mathbf{4 4}$ \\
\hline
\end{tabular}

The Mean (X) shows that the students from the experimental group had an average score of 45.5 , which means that the group, as a whole, only got the $45.5 \%$ of 100 points possible ( 45.5 out of 100). On the other hand, The Mean (X) of the control group shows that students got $44 \%$ of 100 points possible (44 out of 100). Both of them got the low average score in pretest.

\section{POST-TEST FINDING}

The post-test was given after intervention phase to the students. The experimental group, different to the control group, was taught using Instagram picture series as teaching media. Teacher gave the example of writing procedure text by making caption and posting a 
picture series of making food or beverage. Then, asked the students to post their own picture and caption as the post-test. Once the groups done it, the researcher composed it, scored it with the rubric, and then analyzed the data. The analysis of the post-test scores of the experimental group showed that the amount of students with good performance was ten (10). On the other hand, the results from the control group showed six (6) students with average performance, three (3) students with good performance and one (1) with very good performance. Table 3 shows the post-test scores for both groups as follows:

Table 3. Post-test results of experimental and control groups

\begin{tabular}{cccc}
\hline $\begin{array}{c}\text { Experimental } \\
\text { Group }\end{array}$ & Pre-Test Score & Control Group & Pre-Test Score \\
\hline SE1 & 80 & SC1 & 70 \\
SE2 & 70 & SC2 & 65 \\
SE3 & 80 & SC3 & 65 \\
SE4 & 75 & SC4 & 65 \\
SE5 & 80 & SC5 & 75 \\
SE6 & 80 & SC6 & 65 \\
SE7 & 70 & SC7 & 65 \\
SE8 & 85 & SC8 & 60 \\
SE9 & 85 & SC9 & 80 \\
SE10 & 75 & SC10 & 90 \\
\hline
\end{tabular}

To calculate the post-test Mean (X) or average score the researcher used the same procedures as in the pre-test.

Table 4. The mean of the post-test

\begin{tabular}{ccc}
\hline Group/ Mean & $\begin{array}{c}\text { Experimental } \\
\text { group pre-test }\end{array}$ & $\begin{array}{c}\text { Control group pre- } \\
\text { test }\end{array}$ \\
\hline Mean $\mathrm{X}$ & $\mathrm{X}=780 / 10$ & $\mathrm{X}=700 / 10$ \\
$\sum \mathrm{x} / \mathrm{n}$ & $\mathrm{X}=\mathbf{7 8}$ & $\mathrm{X}=\mathbf{7 0}$ \\
\hline
\end{tabular}

The Mean (X) shows that the students from the experimental group got an average score of 78 , which means that the group got the $78 \%$ of 100 points possible. On the other hand, The Mean (X) of the control group shows that students got an average score of 70 , which means that the group got the $70 \%$ of 100 points possible. Both of them got the good average score in post-test.

\section{PRE-TEST AND POST-TEST ANALYSIS}

A comparative analysis of the findings from the pre-test and the post-test exposed a significant growth in the average performance or mean of both groups. But, the percentage growth of the experimental group is higher than the control group. The experimental group went from 45.5 to 78 , showing a growth of $41.66 \%$. On the other hand, the control group went from 44 to 70 , with a total growth of $37.14 \%$. To calculate the growth the researcher used this following formula:

Percentage of Growth $=\frac{(\text { Post test }- \text { Pre test })}{\text { Post test }} \times 100$ 
Table 5. Pre-test and post-test mean (X) percentage of growth

\begin{tabular}{cccc}
\hline $\begin{array}{c}\text { Group of } \\
\text { Students }\end{array}$ & Pre-test & Post-test & Growth \\
\hline Experimental & 45.5 & 78 & $41.66 \%$ \\
Control & 44 & 70 & $37.14 \%$ \\
\hline
\end{tabular}

Based on Table 3, the percentage growth's margin between experimental group and control group is $41.66 \%-37.14 \%=\mathbf{4 . 5 2} \%$. That margin percentage is quite significance compared with the null hypothesis standard margin $0,5 \%$. This finding revealed that the use of Instagram picture series as teaching media could improve the students' ability in writing procedure text.

\section{DISCUSSION}

The reason why picture series were used to teach procedure text is because pictures story speaks thousands of words, it can be very effective way of teaching and learning English language especially in teaching and writing, as Heaton (1988, p. 142) says that a pictures story are very useful. It is not only used as the basic material for student's composition but also it is effectively stimulates students' imaginative power. So that pictures story can be very effective way of teaching and learning the English Language especially writing. Furthermore, Raimes $(1983$, p. 36) says that a picture sequence, such as comic strip, provides the subject matter for writing narrative and for speculating about the story beyond the pictures in the strip. A set of parallel picture - pictures that show a similar scene or tell a similar story - provides material that offers guidance on vocabulary, sentence structure, and organization yet lets the students write about new subject matter.

Wright (1997) suggests the use of picture series. According to him, pictures series are pictures, which show some actions or events in chronological order. They tend to range from four to eight pictures. They usually tell some short of stories, but they may also be used to depict a process how to make something. In addition, Wright (1997, pp. 72-74) states that picture sequence can highlight certain language features and it can illustrate a story or a process. The literature reviewed by the researcher regarding picture in language teaching (Bowen, 1991; Hill, 1990; Raimes, 1983; Wright, 1990) maintain that incorporating picture to language teaching and learning has positive effects on the improvement of learners' communicative skills. These resources help teachers to contextualize language by connecting the classroom with the world outside its walls. They also encourage students to use the target language by providing support or a reference point to write or talk about. In this regard, Wright (1990, p. 2) affirms that pictures "contribute to: 1) interest and motivation; 2) a sense of the context of the language; and 3) a specific reference point or stimulus". The adaptability of pictures to any kind of communicative tasks is reported by Raimes (1983, p. 28) who states that "pictures provide a shared experience for students in the classroom, a common base that leads to a variety of language activities".

Bruce \& Hogan (1998) say "technology is always embedded in everyday discourse and activity". Technology becomes normal and expected means of communication and education. In addition, Cummins (2000, p. 539) says "rather than dismissing IT as many critical educators have tended to do, or lamenting its perspective impact on educational priorities, we should acknowledge the fundamental changes that IT is bringing to our societies and seek ways to use its power for transformative purposes". Moreover, the use of 
various applications through computers and smartphones has paved the way for teachers to innovatively shape their strategies and approaches in language teaching and learning. In fact, by applying social media in language classroom, namely Facebook, Instagram, Blogs, and Twitter, learners will be highly motivated to interact socially with their peers.

Bell (2013) conducted similar study using Instagram and disclosed that Instagram has played a major role in enhancing the subjects learning whereby communication took place in the form of expressing ideas and feelings in their captions in Instagram. Further, he claimed that written communication helps in the process of building up self-esteem and confidence in everyday lives. Salomon (2013) agreed and added that Instagram has gained a person's interest as well as confidence in expressing ideas virtually.

Finally, it has been found that students can become more actively involved through the use of visual materials. It has been registered that students seems to be more motivated and involved in the writing tasks when using pictures because these resources provide a stimulating focus for students' attention (Raimes, 1983). In a 2012 paper, Uematsu reviewed important contributions of pictures to language teaching, looking in particular at the motivational factors provided by pictures. Uematsu summarizes that pictures help teachers to teach better and students to learn better. He has also found that pictures have the attribute to engage students in their learning given that they are appealing resources for students. This study supports the previous studies that the use of visual material/ picture series/ Instagram can be effectively enhance students' competence in writing procedure text.

\section{CONCLUSION}

As presented in finding that the percentage growth's margin between experimental group and control group is $41.66 \%-37.14 \%=\mathbf{4 . 5 2} \%$. It can be concludes that the use of Instagram picture series as teaching media was an appropriate strategy for eleventh grade students of Madrasah Aliyah NU Sidoarjo to improve their ability in writing procedure text. It means that, the use of Instagram picture series as teaching media had the significant positive impact to the improvement of the students' ability in writing procedure text.

\section{REFERENCES}

Barbe, W. B., \& Milone, M. N. (1981). What we know about modality strengths. Educational Leadership.

Bell, M. A. (2013). Picture this! Using Instagram with students.Internet@Schools, 20(4), pp. 23-25.

Bowen, B. M. (1991). Look here! Visual aids in language teaching. London: Modern English Publishers.

Bruce, B. C., \& Hogan, M. P. (1998). The Disappearance of Technology: Toward an Ecological Model of Literacy. Florence, KY: Routledge. [ISBN: 978-0-8058-2642-5]

Coffin, C., Curry. M.J., Goodman, S., Hewings, A., Lilis, T.M., \& Swann, J.(2003). Teaching Academic Writing: A Toolkit for Higher Education. London and New York: Routledge.

Cummins, J. (2000). Language, Power and Pedagogy: Bilingual Children in the Crossfire.Clevedon: Multilingual Matters.

Dunn, R., Dunn, K., \& Price, G. E. (1988). Productivity Environmental Preference Survey. Lawrence, Kans.: Price Systems, Inc.

Gerot, L., \& Wignel, P. (1994). Making Sense of Functional Grammar. Sydney: Gerd Stabler. 
Hadfield, C., \& Hadfield, J. (2004). Writing Games. Edinburg: Longman Pearson Education Limited.

Harmer, J. (2004).How to Teach Writing. England: Pearson Education Limited.

Heaton, J. B. (1988). Writing English language tests. London: Longman.

Hill, D. A. (1990). Visual Impact. Creative language learning through pictures. London: Longman Group UK limited.

Lunden, I. (2014), January 21. Instagram Is The Fastest-Growing Social Site Globally, Mobile Devices Rule Over PCs For Access. TechCrunch. Retrieved June, 2019. fromhttp://techcrunch.com/2014/01/21/Instagram-is-the-fastest-growing- social-siteglobally-mobile-devices-rule-over-pcs-for-social-access/

Mueller, D. (1992). An Interactive Guide to Educational Research. Needham Heights: Concordia University.

Raimes, A. (1983). Technique in Teaching Writing. New York: Oxford University Press.

Salomon, D. (2013). Moving on from Facebook Using Instagram to connect with undergraduates and engage in teaching and learning. College \& Research Libraries News, 74(8), pp. 408-412.

Tim FasilitatorBahasa Inggris. (2006). AsyikBelajardengan PAKEM (PembelajaranAktif, Kreatif, Efektif, danMenyenangkan). Jakarta: Managing Basic Education.

Tim PelatihPenelitian Tindakan (Action Research) Universitas Negeri Yogyakarta. (2000). Penelitian Tindakan (Action Research). Yogyakarta: Direktorat Pendidikan Menengah dan Lembaga Penelitian Universitas Negeri Yogyakarta.

Uematsu, H. (2012). The use of pictures and illustrations in teaching English. 21st Century Education Forum, 45-50.

Wright, A. (1990). Pictures for language learning. Cambridge: Cambridge University Press. 